\title{
Covid-19 Salgını, Ekonomik Etkileri ve Küresel Ekonominin Geleceği
}

\section{Covid-19 Outbreak, Economic Effects and Future of Global Economy}

\author{
İbrahim ARSLAN ${ }^{a *}$, İlyas BAYAR ${ }^{\mathrm{b}}$
}

${ }^{a}$ Prof. Dr., Gaziantep Üniversitesi, İ̈BF, İktisat Bölümü, Gaziantep / TÜRKIYE

ORCID:0000-0003-4638-2676

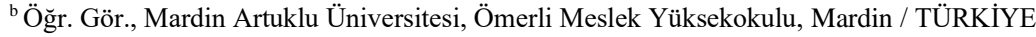

ORCID:0000-0003-3921-8747

\section{A K A L E B İL G ÍS İ}

Makale Geçmiși:

Başvuru tarihi: 24 Temmuz 2020

Kabul tarihi: 26 Ağustos 2020

\section{Anahtar Kelimeler:}

Covid-19,

Küresel Ekonomi,

İktisat Politikaları.

\section{A R T ICLE INFO}

Article History:

Received July 24, 2020

Accepted August 26, 2020

\section{Keywords:}

Covid-19,

Global Economy,

Economy Policies

\section{ÖZ}

Çin'in Wuhan kentinde başlayıp kısa sürede dünyaya yayılan Covid-19 salgınının neden olduğu vaka sayısını düşürmek, ölüm sayılarını azaltmak ve pandeminin yayılma hızını kontrol altına almak için devletlerin iktisadi aktiviteleri yavaşlatma kararı ve bu sürecin ne kadar süreceğinin belirsizliği 2008 küresel finansal krizi sonrası düșük büyüme ile süregelen ve ekonomik dengeleri derinden sarsmıştır. Bu süreç öncelikle insan ve halk sağlığına dönük önlemler önem arz etse de yaşamsal fonksiyona dayanan ekonomik durumun görünümüne dair bir projeksiyon gereklidir. Yapılan çalıșmada Covid-19 salgınının genel olarak küresel çapta özel olarak da gelișmekte olan ülkelerde olası ekonomik etkileri irdelenmeye çalışılmıştır. Belirsizlik durumu ile birlikte doğal bir biçimde bu yıl küresel ölçekte ekonomik daralmanın yaşanacağı noktasında uluslararası ekonomik kurum ve kuruluşların raporlarında bir uzlaşı vardır. Hem talep hem de arz şokunun birlikte olduğu bir dönemde gelișmekte olan ülkelerin para birimlerinin rezerv para olmaması, mevcut borçlar ile birlikte artan borç yükleri ve de pandemi sürecinden dolayı yaşayacakları dıș gelir kaybı nedeni ile daha fazla etkilenecekleri tahmin edilmektedir. Kriz bulaşıcılığının anlam kazandığı bu süreçte 2008 küresel finans krizinden elde edilen tecrübelerle gelişmiş ülke ekonomilerinin gelişmekte olan ülkelerle işbirliği sağlamak suretiyle dünya piyasalarının sağlam bir zemine oturacağını tespit edip bu yöndeki politika uygulamaları önemlidir. Bu süreçte en büyük handikap hem sosyal hayat hem de iktisadi açıdan belirsizlik durumunun varlığıdır. Davranışsal ekonomi bağlamında iktisadi aktörlerin seçim ve tercihlerine dair kararlarda belirsizlik ve risk parametrelerini göz önünde bulundurmaları kaçınılmazdır. Pandemi sonrası gelișmiş ülke uygulamalarına benzer bir tarzda gelişmekte olan ülkelerin mali politikalar alanında kurala dayalı bir model oluşturmaları gereği ortaya çıkacağı düşünülmektedir.

\section{A B S T R A C T}

The slowdown decision of the governments for the economical activities and the uncertainty of how long this process will continue in order to reduce the number of cases caused by the Covid-19 epidemic that started in Wuhan. China and spread to the world in a short time, to decrease the number of deaths and to control the pandemic spreading rate, has shaken the ongoing and economic balances with the low growth after the 2008 global financial crisis. Although this process is primarily important for human and public health measures, a projection of the appearance of the economic situation based on vital function is required. In this study, it was tried to examine the possible economic effects of Covid-19 epidemic globally in general and especially in developing countries. Along with the uncertainty, there is a consensus in the reports of international economic institutions and organizations on the point that there will be a global economic contraction this year. It is estimated that the currencies of the developing countries will be affected more due to the lack of reserve money, the increasing debt burden along with the existing debts, and the loss of foreign income due to the pandemic process, at a time when both demand and supply shock are together. In this process where crisis contagion becomes meaningful, it is important to determine that the developed countries' economies will sit on a solid ground by cooperating with developing countries, with the experience gained from the 2008 global financial crisis and policy practices in this direction are important. The biggest handicap in this process is the existence of uncertainty both in social life and economically. Within the context of behavioral economics, it is inevitable for economic actors to take into account the uncertainty and risk parameters in their decisions regarding their choices and preferences. It is thought that in the developing countries there will be formed a a rule-based model in the field of fiscal policies, which are similar to the practices of developed countries after pandemic.

\footnotetext{
* Sorumlu yazar/Corresponding author.

e-posta: arslan@gantep.edu.tr
} 


\section{EXTENDED ABSTRACT}

The Covid-19 (Coronavirus) epidemic appears as an event that started in China and affected the world in a short period of time and caused it to be described as a pandemic due to its transcontinental spread character. However, when compared to the past centuries the thing that make this process different is the addition of new ones (entrepreneur, technology, knowledge) to the production factors that provide economic growth, the increase in the amount of goods and services produced on the supply front in real terms in the world, and accordingly, the changes in consumer preferences and consumption patterns on the demand. In terms of financial markets, with the globalization, new changes and transformations are experienced with the change of derivative markets, commodity trading and energy supply as the primary source of energy. In this study, the effects of coronavirus (Covid19) epidemic on both global and developing countries and its possible consequences will be discussed.

The Covid-19 outbreak is an economic crisis that has a non-economic (natural disaster [epidemic]) with a nature of an economic crisis that spreads from a local / regional ground to a global ground, which occurs suddenly and unexpectedly, in line with the definition of the economic crisis. When the global economy is considered in terms of macroeconomic indicators, the real terms such as shrinking economies, increasing unemployment rates and decreasing international trade movements the world faces a serious economic crisis in terms of the financial sector, especially the capital and liquidity problem. The question of the difference or similarity of the crisis from the previous crises was one of the most frequently asked questions in every platform where the economic effects of the epidemic were discussed after the Coid-19 epidemic. The most obvious difference of this crisis from others is that the crisis is not a macro-economic or financial source, but the triggering factor is a virus.

The most crucial aspect of the Covid-19 crisis is that it has a state of "uncertainty". The uncertainty of the pandemic control process and further prolongation of the process will cause production restrictions in both developing and ever-developing countries. The view that this process will continue for policy makers is dominant until there is any cure or vaccine against the disease. The report, which includes the economic outlook and growth expectations estimates published by the World Bank, is unprecedented in the report and despite the implementation of these practices, it is currently that the GDP will shrink by 5.2\% globally for 2020. OECD, on the other hand, expressed its predictions and forecasts on whether there would be a second wave in the virus. If there is no second wave in the virus, the world's economy will shrink by $6 \%$ in 2020 , if there will be a second wave, it is expected that the world economy will shrink by 7.6\%. In April 2020, the International Monetary Fund revised its growth rate, which was projected as $3 \%$, by 1.9 points, to $4.9 \%$. For the year 2021 , the forecasting of the global economy is $5.4 \%$ (developed economies $4.8 \%$ and developing countries $5.9 \%$ ).

In order to overcome the 2008-09 Global Financial Crisis, monetary, fiscal and macro prudential measures have been coordinated and integrated. Similar policy reactions and practices have been important in this crisis in terms of demonstrating the lessons learned from the 2008-2009 crisis. With the spread of the Covid-19 outbreak, the countries have provided large-scale macroeconomic support to prevent the deepening and effects of the global economic crisis. Within this context, both governments and monetary authorities have taken steps to prevent economic and financial collapse. The reasons for the high probability of being affected by the global shock in developing countries can be addressed under two main headings. These are global shocks and structurally sourced conditions. The decrease in exports, primarily raw materials, which are effective in determining the growth sources of developing countries (due to the shock of foreign demand), decrease in foreign exchange workers who provide foreign currency input, tourism, which is an important source of foreign exchange, and decrease in services, the decrease in the prices of commercial goods and financial markets is difficult and costly to reach. Brent crude oil prices fell by $63 \%$ in this process due to the global demand decline. When other commodities were added to the analysis (industrial metals, precious metals (excluding gold), agriculture and animal husbandry), the overall price decline was $37 \%$.

According to the report prepared by the International Finance Institute (IIF), global debt broke a new record in 2019 and became 255 trillion dollars. The addition of developing markets to global debt has exceeded $\$ 3.4$ trillion and total debt has exceeded $\$$ 71 trillion. In developing countries, while the debt/GDP was $147 \%$ in 2007, this rate reached $220 \%$ and it was recorded as the highest level. Besides the global debt level reaching very high levels, another striking point is the expansion of the gap between the real economy and the virtual economy. As a matter of fact, considering that the market value of global goods and services is close to 90 trillion dollars, it is alarming that there are no goods and services produced in return for the said amount of debt.

After the pandemic, the first step that should be taken is to decrease the indebtedness rate so the developing countries should not fall into the vortex of a new crisis. It should not be forgotten that the financial instability that will emerge after the Global financial crisis experienced in the 21 st century and Keynesian policies, which are seen as a guide and solution, in other words, the public debt stock will be loaded to future generations. Beyond the Ricardo-Barro hypothesis, this problematic situation will not be solved by either a purely liberal understanding or an overregulated state model. Above all, it will ultimately require fiscal rules to lean economies into staggering economies towards consumption. 


\section{Giriş}

Covid-19 (Koronavirüs) salgını Çin'de başlayıp kısa bir zaman diliminde dünyayı etkileyen ve de kıtalararası yayılma karakterine sahip olmasından dolayı pandemi olarak nitelendirilmesine sebep olan bir olay olarak karşımıza çıkmaktadır. İnsanlık tarihi daha önce de benzer hadiseler/vakıalarla karşı karşıya gelmiştir. 14. yy'da özellikle de Avrupa'yı derinden etkileyen ve Kara Ölüm olarak da ifade edilen Veba Salgını, 1918'de yaşanan ve 50 milyon insanın ölümüne neden olan İspanyol gribi/nezlesi bu türden örneklerdir. Fakat bu süreci farklı kılan geçmiş yüzyıllarla karşılaştırıldığında iktisadi büyümeyi sağlayan üretim faktörlerine yenilerinin (girişimci, teknoloji, bilgi) eklenmesiyle dünyada reel açıdan arz cephesinde üretilen mal ve hizmet miktarının devasa bir biçimde artması, buna bağlı olarak da talep cephesinde tüketici tercihlerinin ve tüketim kalıplarının değişmesi, finansal piyasalar açısından da küreselleşme ile birlikte türev piyasaların, emtia alım satımının ve enerjinin başat kaynağı olarak petrol arzının değişmesiyle yeni değişim ve dönüşümün yaşanıyor olmasıdır.

İnsanların ve toplumların sürekli yeni bir arayış içinde olmaları, ilerlemeye ve gelişmeye dönük bir düzlemde hayatlarını farklı kılma istekleri sosyal hayatın yanı sıra tüketim alışkanlıklarının zenginleşip farklılaşmasına olanak sağlamıştır. Bu bağlamda ekonomik açıdan "üretim-tüketim-üretim" sarmalının sürekliliği ancak sağlam ve istikrarlı bir iktisat politikası zemini ile mümkündür. Covid-19 salgını bireylerin yaşam biçimlerini salt informel olarak değil formel anlamda da kökten değiştirmektedir. Nitekim sosyal izolasyon ve fiziki mesafe ile insan ilişkilerinin derinden etkilendiği gerçeği önemli bir husustur. Bunun yanı sıra devlet erkinin idari işlerinin, yargısal faaliyetlerinin yavaşlatılması, spor müsabakalarının askıya alınması, çalışma koşullarının ve eğitimin online (çevrimiçi) bir biçim alması gibi akla ilk gelen hususlardan olsa da sosyal ve kültürel yaşamda çok daha fazlasının yaşandığı bir süreçtir.

Salgın, ekonominin reel yönüyle mal, ücret ve faktör piyasalarını; finansal yönüyle de para politikası otoritesi Merkez Bankası başta olmak üzere, bankacılık vb. kurumların tercihlerini ve ihtiyati politikalarını etkileyerek ekonomik ilişkiler ağını başka bir mecraya evirmiştir. Bu sürecin hastalık ve ölümle neticelenmesi ekonominin arz ve talep ayağını derinden etkilemiştir. Fiziki ve sosyal izolasyon ile temassız hayat üretim ayağı üzerinden işgücü arzını etkileyerek tarım, sanayi ve özellikle de hizmet sektöründe arzın daralması ile neticelenmiştir. Benzer bir biçimde yaşamsal nosyona dayalı mal ve hizmetlere olan talep hariç tutulursa kaçınılmaz bir şekilde talep daralması karşı karşıya kalınacak bir sürece girilmektedir.

Piyasada arz ve talebin daralması ekonomik resesyon ile neticelenirse ve bu durum derinleşirse ekonomik depresyona yol açar. Ekonomik daralma döngüsel bir akış halinde işgücü talebinin azalmasına bu duruma bağlı olarak da satın alma gücünü düşürerek yoksulluğun artmasına temel tüketim maddelerinin dâhi karşılanamamasına neden olur. Bununla birlikte sermaye sahiplerinin ve farklı ölçekteki işletmelerin üretimlerini durdurmaları ve özellikle de işletmelerin sağlam bilanço yapısına ve optimal rasyolara sahip olmamaları ekonomik durgunluğu derin bir şekilde tetikleyecektir.

İktisadi aktörlerin verili durumları ile bir üretim aktörü, denge ve denetleyici fonksiyona sahip kamu otoritesi ile birleştiğinde resimdeki objeler ve bu objeler arasındaki ilişki ağı ve etkileşim düzeyi karmaşık hale gelir. Sağlıklı ve işlevsel politikaların hayata geçirilememesi siyasi kaos ve en sonunda toplumsal kaos ile neticelenir. Bu süreçte fark edilecek hususların başında ülkelerin gelişmişlik durumları nazara alındığında özellikle kırılgan yapıya sahip gelişmekte olan ülkelerin gelişmiş ülkelere nazaran daha çok etkileneceği gerçeğidir. Gelişmiş ülkelerin para birimlerinin rezerv para olarak dünya ölçeğinde kullanılması, yatırımları finanse edecek tasarruflar açısında otarşik bir yapıya sahip olmaları, finansal yapıların sağlamlığı ve tek hedef olarak enflasyona odaklanmaları para politikası açısından; koydukları mali kurallar sayesinde mali politikalar açısından daha avantajlı oldukları gerçeği gelişmiş ülkelere önemli 
avantajlar sağlamaktadır. Gelişmekte olan ülkelerin tasarruf açıklarının uluslararası sermaye hareketleri vasıtasıyla yatırım yapabilmesine imkan sağlaması pandemi sürecinde gelişmekte olan ülkeleri en çok etkileyecek husus olarak karşımıza çıkacaktır. Gelişmekte olan ülkelerde krizin yıkıcı etkilerinden biri de bozulacak olan tedarik zincirinin çıktı azalmasına yol açarak işsizlik oranının artmasına neden olması sorunudur. Gelişmiş ülke ekonomilerinde enflasyon stabil bir seyir izlerken gelişmekte olan ülkelerde döviz kuru ve buna bağlı olarak ihracattaki ithal girdi kullanımı ve para otoritelerince kaynak elde etmek için para basma gereği enflasyon yaratabilir. Potansiyel bir ekonomik krizin habercisi olarak Covid-19 süreci makro iktisadi politikaların belirli bir dönem ya da şartlara bağlı kalmaksızın krizleri önleyecek bir model/mekanizma kurma gerekliliğine ihtiyaç duyulduğunu göstermektedir. Fakat gelişmekte olan ülkeler sahip oldukları insan kaynağını sermaye akışı ve faizlerin bu denli düşük olduğu küresel bir ortamda yatırımı finanse edecek bir mekanizma ile entegre hale getirirlerse bu durumun firsata çevrilmesi olanağı doğacaktır.

2008-09 krizine benzer bir biçimde ve isabetli olarak otoritelerin parasal genişlemenin yanı sıra Keynesyen çözüm politikalarına odaklanmaları seçeneği gelişmekte olan ülkeler için yeniden gözden geçirilmelidir. Bu seçeneğin düşünülmesi bu doğrultuda alınacak kararların ertelenmesi anlamına gelmemelidir. Yalnızca gelişmekte olan ülkelerin pandemi sonrası makro ekonomik dengelerini değiştirecek en önemli unsur olarak mali politikalar ve kamu borçlanmasının yarattı̆̆ı durumun hatırda tutulması gereğidir. Bu süreç gelecekte makro anlamda ülkelerin bütçelerini oluştururken, para arzını yönetirken; mikro anlamda üreticilerin üretime karar verirken ve bilançolarını oluştururken ve tüketicilerin tüketim-tasarruf tercihlerini yeniden gözden geçirerek ihtiyatlarını arttırmasını salık verecektir. Bu hususların yanı sıra yeni dönemde dünya piyasaları şu sorulara cevap bulma arayışına gireceklerdir. Üretimde insan faktörü değerini yitirecek mi? Robotik ve otomasyona dönük bir üretim yapısı gelişmekte olan ülkeleri nasıl etkileyecek? Parasal genişleme ile varlık balonları patlayacak mı? Metro hatları seferi azaltılacak, seyahatlerde yolcu sayısı sinırlandırılacak mı? Bu türden sorunlar ve olas1 maliyetler ne şekilde tezahür edecektir.

Yapılan çalışmada koronavirüs (Covid-19) salgınının hem küresel anlamda hem de gelişmekte olan ülkeler üzerinde yaratacağı etkiler ve doğuracağı olası sonuçlar ele alınmaya çalışılacaktır. Bu bağlamda ikinci bölümde Covid-19 salgınının küresel ölçekte ekonomik etkileri irdelenmeye çalışılacaktır. Üçüncü bölüm salgının finansal ve döviz piyasasına muhtemel etkileri gelişmekte olan ülkeler özelinde incelenecektir. Son bölümde para, mali ve makro ihtiyati çözüm önerileri sunulmaya çalışılacaktır.

\section{Covid-19 Salgını, Ekonomik Kriz ve Küresel İktisadi Görünüm}

Kriz kavramı etimolojik (kökenbilim) açıdan irdelendiğinde Yunanca "krisis" kelimesine dayanan bilhassa tıp biliminde yaygın şekilde kullanılan bir kelimedir. Beklenmedik bir durumda, ani bir biçimde oluşan hastalık belirtisi veya mevcut bir hastalığın çok ileri bir evreye ulaşması olarak tarif edilir. Sosyal bilimlerde ise kriz "birdenbire meydana gelen kötüye gidiş yönündeki gelişme" buhran, bunalım gibi kavramlarla eşanlamlı olarak kullanılmaktadır. Herhangi bir olayı/olguyu kriz olarak nitelendirmek için ne tür unsurlar olmalıdır sorusu önemlidir. Kriz tanımının esasını oluşturan ve zaman boyutu açısından ele alınması durumunda kriz, önceden bilinmeme ve tahmin edilememe durumudur. Yani beklenmeyen bir şekilde ortaya çıkmasıdır. Kriz ile ilgili önemli hususlardan biri de krizin varlığının bütünüyle negatif bir karaktere sahip olmaması tehlike ve tehdit gibi unsurların yanı sıra kişi ya da örgütlere fırsatlara erişme olanağı sunmasıdır. Krizler kısa ve uzun süreli olmakla birlikte belirgin unsurlardan biri de yayılma etkisi göstermesidir. En nihayetinde ekonomik kriz, bir ekonomide birdenbire ve öngörülemeyen bir biçimde ortaya çıkan mikro seviyede firmaları makro seviyede ise ülke ekonomisini derinden etkileyen ve ciddi olarak sarsan sonuçlar üreten bir süreçtir. Ekonomik krizlerin kaynağı salt ekonomik kaynaklı olmayabilir. Genel olarak reel ve finansal 
sektörlerde meydana gelen talep daralması ya da arz fazlalığı şeklinde ortaya çıksa da doğal afetler de krizin kaynağı olabilir. Tabii felaketlerin yanı sıra politik istikrarsızlık, küresel değişimlere teknolojik açıdan ayak uyduramama gibi birçok unsur ekonomik krizlerin kaynağ olabilmektedir (Aktan ve Şen, 2001:1225-1230).

Covid-19 salgını ekonomik krizin tanımına uygun bir şekilde ani ve beklenmedik bir biçimde ortaya çıkan yerel/bölgesel bir zeminden küresel bir zemine yayılan ekonomik kaynaklı olmayan (doğal felaket kaynaklı [salgın]) bir ekonomik krizdir. Şüphesiz öncelenmesi gereken ve dünya çapında da genel olarak politikalarda eğilimin bu yönde olduğu durum insan ve halk sağlığıdır. İnsan sağlığı ile birlikte bu süreçte ekonominin durumu daha çok ön plana çıkmıştır. Küresel ekonomi makro iktisadi göstergeler açısından ele alındığında daralan ekonomiler, artan işsizlik oranları, uluslararası ticaret hareketlerinin azalması gibi reel yönüyle; sermaye ve likidite sorunu başta olmak üzere finansal sektör açısından dünya çok ciddi bir şekilde ekonomik kriz ile karşı karşıya bulunmaktadır. Acemoğlu (2020) bu sürecin/salgının çok derin ekonomik etkilerinin olacağını ifade ettikten sonra pandeminin 1918 İspanyol Gribi/Nezlesi, 1929 Büyük Buhranı ve 2008 Finansal Krizinin her üçünün elemanlarını barındıran bir kriz olarak tarif eder. Açıkçası bu süreç ne her arzın kendi talebini yaratması krizi ne de efektif talep yetersizliğini gidermek için meydana gelmiş bir krizdir. Covid-19 salgını sonrası salgının ekonomik etkilerinin tartışıldığı her platformda en çok sorulan soruların başında krizin önceki krizlerden farkı ya da benzerliği sorusu idi. Bu krizin diğerlerinden en belirgin farkı krizin makro ekonomik ya da finansal kaynaklı olmayı tetikleyici unsurun bir virüs olmasıdır.

Dünya Sağlık Örgütü Genel Sekreteri Tedros Adhonom Gheloregesus, 11 Mart 2020'de yaptığı toplantıda Çin'in Hubei Bölgesinin başkenti Wuhan'da başlayan Covid-19 salgınının vaka sayısının 13 kat ve etkilenen ülke sayısının 3 kat arttığını dile getirmiştir. 114 ülkede 118 binden fazla vaka ve 4291 kişinin hayatını kaybettiğini ifade ettikten sonra Gheloregesus, gelecek günler ve haftalarda vaka sayısının, ölüm sayısının ve etkilenen ülke sayısının daha da artacağını beklediklerini dile getirerek ciddi ve endişe verici yayılma hızı nedeni ile pandemi olarak nitelendirilmesi gerektiği değerlendirmesini yapmıştır (WHO, 2020a). Genel Sekreter Ghebreyesus yaklaşık 3 ay sonra 13 Temmuz 2020'de 12 Temmuz Pazar günü Dünya Sağlık Örgütü'ne 230 bin Covid-19 vakasının bildirildiğini ve bu vakaların neredeyse \% 80'nin 10 ülkeden kaynaklandığını dile getirerek gerekli önlemlerin alınmaması halinde salgının etkisinin artacağını çok daha kötü günlerin dünyayı beklediğini ifade etmiştir (WHO, 2020b). 13 Temmuz itibariyle dünya genelinde Covid-19 tanısı konulan kişi sayısının 13 milyonu geçtiği ifade edilmektedir.

Çin'den dünyaya yayılan Covid-19 virüsü dünyanın her tarafında yaşamını sürdüren insanların hayatlarını şiddetli bir biçimde sarsmıştır. Covid-19 salgını sürecinde entübe, filyasyon, pandemi, $\mathrm{R}_{0}$ gibi kavramlar hayatın olağan akışı içerisinde yerini almıştır. İnsanların sağlığ ciddi bir tehdit altında olduğundan ekonomik faaliyetler durma noktasına gelmiş ve refah seviyesi derinden etkilenmiştir. Salgının yayılma hızını azaltmak için hükümetler ekonomik faaliyetleri askıya almak zorunda kalmışlardır. Covid-19 Salgınının yayılmasını engellemek için kamu otoritelerinin aldığı önlemlerin bazılarını aşağıda sıralamak mümkündür:

- $\quad$ Birçok sektörde üretim faaliyetlerinin askıya alınması.

- $\quad$ Ağırlıklı olarak hizmet sektörü faaliyetlerinin durdurulması.

- Uluslararası ticaretin kesintiye uğraması.

- Hem yurt içinde hem de yurt dişında seyahat kısıtlamaları.

- $\quad$ İdari faaliyetlerin, hukuki davaların sürdürülmekle birlikte minimal bir seviyeye indirilmesi. 


\section{sürdürülmesi. \\ Eğitim faaliyetlerinin online biçimde uzaktan eğitim şeklinde}

Özel sektörde bankacılık, sigortacılık başta olmak üzere birçok sektörde home ofis biçiminde çalışılması.

Salgının yansımaları esasında ekonominin doğası gereği karmaşık, etkileşimli ve domino etkisi yaratan bir süreçtir. Küresel çapta yaşanan ekonomik krizlerin tetikleyici unsurları her dönem farklı şoklardan kaynaklanmıştır. 1929 yılında Büyük Buhran olarak adlandırılan ve New York Piyasasının çöküşü ile neticelenen ve tüm dünyaya sirayet eden kriz esasında her arzın kendi talebini yaratmadığı bir talep şoku krizidir. 2008-9 krizi ise özellikle konut fiyatlarının inişe geçmesiyle subprime mortgage (düşük gelir grubuna verilen yüksek faizli kredi) olarak ifade edilen ve kredi piyasasının çökmesiyle sonuçlanmış bir finansal kriz idi. 2019 yılının sonlarında Çin'de görülen ve daha sonra dünyaya yayılan virüs nedeni ile yaşanan kriz, arz şoku ile başlayıp talep şokuyla devam eden ikiz şok bir şeklindedir. Daha açık bir ifade ile krizin kaynağı ekonomik açıdan esas itibariyle reel sektörden kaynaklı bir arz şokunun işgücü piyasası ve finansal piyasayı etkileyerek talep şokuna neden olmasıdır.

Kriz süreçlerinde uygulanacak olan makro iktisat politikalarına en büyük engel belirsizlik durumudur. $\mathrm{Bu}$ süreçlerde belirsizlik engelinin nispi olarak azalmasını gösteren sinyallere ihtiyaç duyulmaktadır. Bunlardan biri en azından sürecin sosyo-ekonomik ayağının seyrini değiştirecek unsur olarak istifade edilebilecek gösterge A.G. Kermack ve McKendrick $(1927,1932,1933)$ tarafından geliştirilen SIR modelidir. Bu model belirli varsayımlar altında bulaşıcı hastalıkların yayılma hızını tahmin eden bir çalışmadır. SIR modeli ismini modeli oluşturan 3 unsurun ilk harflerinden hareketle almıştır. Bu unsurlar (Jones, 2007:1; Akpınar, 2012:99; Kılıç, 2020: Müftüoğlu, 2020; Acemoğlu; 2020): Susceptible (S): Hastalığa henüz yakalanmamış ve yakalanmaya açık sağlıklı bireyler; Infectious(I): Hastalığa yakalanmış/Enfekte olmuş/ hasta bireyler; Recovered/Removed (R): İyileşen ve hastalığa bağışıklık kazanan veya hastalık yüzünden hayatını kaybedenlerdir.

SIR modelinde söz konusu parametreler aracılığıyla cevabı bulunmak istenen sorulardan biri "Hasta veya taşıyıcı biri hastalığı ortalama kaç kişiye bulaştırabiliyor" sorusudur. $\mathrm{R}_{0}$ olarak ifade edilen temel üreme sayısı/oranı bulaşıcı hastalığın bulaşıcılık derecesini matematiksel olarak ifade ediyor. $\mathrm{R}_{0}$ 'ın hesaplanma metodu konumuzun dişında olmak ile birlikte önemli husus $\mathrm{R}_{0}$ değerini 1 ve altına indirmektir. Çünkü $\mathrm{R}_{0}$ değeri hastalığın hasta birinden kaç kişiye yayıldığını gösterir (TÜBA, 2020: 47-50). $\mathrm{R}_{0}$ eğer 1 'in üzerine çıkarsa bulaşıcılığın yeniden artacağı anlamına gelir ki sosyal izolasyona ve fiziksel mesafeye yeniden ihtiyaç duyulur ve bu doğrultuda üretim faaliyetlerinin yavaşlaması ve kısıtlaması zorunlu hale gelir. $\mathrm{R}_{0}$ değeri alınacak önlemler açısından ve belirsizliğin seviyesinin tespiti açısından önemlidir. Bu bağlamda $\mathrm{R}_{0} 1$ 'in altına düştüğü an uygulanan aktif politikaların yeniden revize edilerek devreye girmesi olasıdır. Nitekim Mart 2020'de Dünya Sağlık Örgütü Ro'1 2-2.5 seviyesinde hesaplamıştır.

Covid-19 salgınının ekonomiye muhtemel etkileri makro iktisadi göstergeler yapılacak bir okuma ile açıklığa kavuşur. Şüphesiz bu okuma öngörü ve tahminlere dayalı olduğundan dolayı reel değerlerde sapmalar meydana getirme ihtimali barındırsa da kısa vadeli bir pespektif çizme açısından önem taşır. Dünya Ticaret Örgütü (WTO) Nisan ayının 8'inde yayınladığı raporda Covid-19 salgının küresel çapta olağan yaşam ve ekonomik akviteyi aksatmasının 2020 yılı için dünya ticaretinin \%13 ile \%32 arasında düşmesi ile sonuçlanabileceğini ifade etmiştir (WTO, 2020:1). Hakeza Uluslararası Çalışma Örgütü (ILO) belirsizlik olmakla birlikte tahmin edilen GSYİH düşüşü ile 2019 yılı baz seviyesinden küresel işsizliğin düşük senaryo ile 5,3 milyon; orta senaryo 13 milyon olacağ 1 (7,4 milyonu yüksek gelirli ülke); yüksek senaryo 24,7 milyonu bulacağını tahmin etmiştir. Nitekim 2008-09 Küresel Finansal Krizde 22 milyon kişi 
işsiz kalmıştı (ILO, 18 Mart 2020). OECD (Ekonomik Kalkınma ve İşbirliği Örgütü) Temmuz 2020'nin başlarında yayınladığı ve Covid-19 krizinin istihdama etkisini ele aldığ1 raporda virüsün control edilip edilemediği senaryosu üzerinden 37 üyeye sahip örgütün işsizliğe dair projeksiyonunu güncellemiş ve üye ülkelerde 80 milyon kişninin işsizlik tehlikesi ile karşılaşabileceğini açıklamıştır. Kontrol altına alınmayan salgın neticesinde işsizlik oranının 1929 Büyük Buhran sonrası oranlara tırmanabileciği dile getirilmiştir. 2008 Küresel Finans Krizinin ilk ayları ile karşılaştırıldığında 10 kat daha kötü bir durumla karşı karşıya bulunulduğu belirtilmiş olup hem istihdamdaki düşüş hem de çalışmakta olan kişilerin çalışılan saatlerin azaltılması hususları dikkat alındığında toplam çalışma saatleri 2008' in ilk üç ayında \% 1,2 iken bu oran 2020'de \% 12,2' ye çıkmıştır. OECD, 2019 yılında ortalama \% 5,3'lük olarak kaydettiği işsizlik oranının 2020'nin son çeyreğinde \% 9,4' e çıkabileceğinin ikinci dalga olması halinde de işsizlik oranının söz konusu ülkeler için \% 12,4'e yükselebileceğini ifade etmiştir (OECD, 2020b:22-23).

Makro iktisadi göstergelerden en belirleyici olanı refah artışının da bir göstergesi olan büyüme oranlarıdır. Uluslararası ekonomik kurum ve kuruluşlar küresel ekonominin 1930'lardan bu yana en derin durgunluğu yaşadığını dile getirmektedirler. Dünya Bankası verilerine göre 2008-09 krizi küresel ölçekte dünyayı derinden etkilemesine rağmen 2008 y1lındaki büyüme oranı \% 1,85 iken 2009 yılında negatif büyüme başka bir ifade ile -\% 1,678 küçülme olmuştur ve 2010 yılında dünya \%4,3 büyüme seviyesine ulaşmıştır (World Bank Data, 2020). 2008-09 krizi bir finansal krizdi ve alınan önlemler istenilen sonuçlara ulaşmak noktasında daha açık ve net bir manevra alanına sahipti. Covid-19 krizinin en netameli tarafı bir "belirsizlik" halini barındırmasıdır. Pandeminin kontrol alınma sürecinin belirsizliği ve dahası söz konusu sürecin uzaması hem gelişen hem de gelişmekte olan ülkelerin üretim kısıtlamalarına neden olacaktır. Hastalığa karşı herhangi bir tedavi ya da aşı bulununcaya kadar politika yapıcılar için bu sürecin devam edeceği görüşü hakimdir (World Bank, 2020: xv; OECD, 2020:7).

Dünya Bankası'nın yayınladığı ekonomik görünüm ve büyüme beklentileri tahminlerinin içerdiği raporda daha önceleri benzeri görülmemiş bir biçimde politika desteğine ve bu uygulamaların hayata geçirilmesine rağmen mevcut durumda dünyada küresel ölçekte 2020 y1lı için GSYİH'nin \% 5.2 küçüleceği yönündedir. Hem gelişmiş hem de gelişmekte olan ülkelerde bu nedenle kişi başına gelir düşüşü ile birlikte yoksulluğun artacağı öngörüsü vardır. Bununla birlikte bir bütün olarak ekonomik aksaklıkların yaşanması, makro ekonomik dengesizliklerin artması ve refah azalışının yaşanacağı beklenilmektedir (World Bank, 2020: xv). OECD ise virüste ikinci dalganın olup olmayacağı üzerinden tahminlerini ve öngörüsünü ifade etmiştir. Eğer virüste ikinci bir dalga görülmezse dünya ekonomisinin 2020 yılında \% 6

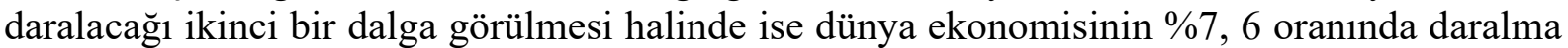
yaşanması beklenmektedir (OECD, 2020:13). Uluslararas1 Para Fonu Nisan 2020'de -\%3 olarak öngördüğü büyüme oranını 1.9 puan düşürürerek -\% 4.9 olarak revize etmiştir. Gelişmiş ülkelerin \% 8 daralacağını (ABD'nin \%8, Euro Bölgesinin \% 10.2); gelişmekte olan ekonomilerin ve yükselen piyasaların \%3 lük bir negatif büyüme ile 2020 senesini tamamlayacaklarını tahmin edilmektedir. 2021 için küresel ekonominin \% 5,4 (gelişmiş ekonomiler \% 4,8 ve gelişmekte olan ülkeler \% 5,9) öngörüsünde bulunulmaktadır (IMF, 2020b).

Salgının ortaya çıkışı birlikte ortaya çıkan ekonomik tablo esasında salgını yavaşlatmak için alınan tedbirlerin bir yansımasıdır. Hem ülkeler arası hem ülke içinde seyahatlerin yasaklanması, sokağa çıkma kısıtlamaları, okulların tatil edilmesi, hizmet üreten (kafe, lokanta vb. yerlerin) AVM'lerin kapatılması bu türden örneklerdir. Salgının gelişmiş ya da gelişmekte olan ülke farkı gözetmeksizin ülke ekonomilerinin hepsini olumsuz etkilediği/etkileyeceği aşikâr olmakla birlikte sürecin ne kadar bir zaman alacağını kestirmek mümkün 
görünmemektedir. Bu bağlamda alınacak ekonomik önlemler sürecin yaratacağı olumsuzlukları minimalize etmesi açısından önemlidir (Aydoğuş, 2020:11-12). Krizin etkilerini azaltmak ve stabil bir iktisadi ortamı sağlamak için parasal genişlemelerin yanı sıra toplam talebi arttırmak için genişlemeci maliye iktisat politikalarının uygulanması noktasında şüphesiz bir uzlaşı vardır (Aydoğuş, 2020:16-17; Çolak, 2020:19; Özatay ve Sak, 2020:7). Nitekim düşük gelir ve yeterli tasarrufa sahip olmayan tüketicilerin gıda ve barınma ihtiyaçlarını karşılamak için nakdi transfer isteği olmuştur. Devletin talep daralması nedeniyle işletmelerin faaliyetlerini sonlandıracak olan iflası ve işsizlik artışını engellemek maksadıyla "son kertede alıcı" olarak devreye girmesi gerekir. Daha açık bir ifade ile mali paketlerle değer zincirinin kırılmasını engelleyecek tedbirler genel bir talep düşüşünü engelleyeceği savunulmaktadır (Özatay ve Sak, 2020:3).

2008-09 Küresel Finans Krizini aşmak için para, maliye ve makro ihtiyati tedbirler eşgüdüm ve entegre bir şekilde uygulanmıştı. 2008-09 ekonomik krizi öncesi Merkez Bankaları genel olarak enflasyon hedeflemesi çerçevesinde tek hedef olan enflasyon oranı ve bu hedefi sağlayacak olan araç olarak da kısa dönem politika faiz oranına odaklanırken kriz ile birlikte para politikası "çok araç" ve "çok hedef" politikasına yönelmişlerdir (Bilanchard vd., 2019:8; Yellen, 2009:33). Bu krizde de benzer politika reaksiyonları göstermek ve uygulamak 20082009 krizinden alınan dersleri sergilemek açısından önemli olmuştur. Covid-19 salgınının yayılması ile birlikte küresel ekonomik krizin derinleşmesini ve etkilerini engellemek için ülkeler büyük ölçekli makro ekonomik destek sağlamışlardır. Bu bağlamda hem hükümetler hem de para otoriteleri ekonomik ve mali çöküşü engelleyecek adımları atmışlardır. Sosyal transferler, işçilerin gelirlerini korumak ve şirketlerin borçlarının vadelerini uzatmak gibi politikalar uygulamışlardır. Para politikası kanalı ile Merkez Bankaları politika faizleri düşürmek suretiyle piyasaya likidite sağlamış, finansal kuruluşlar eliyle kredi sağlanarak yatırımcının güvenini kazanacak politik hamlelerin yanı sıra 2008-09 krizi esnasında yapılandan daha fazla bir şekilde genişletici maliye politikaları uygulamaları yapılmıştır (OECD, 2020:12; World Bank, 2020:3).

Bu bağlamda Avrupa Merkez Bankası Yönetim Konseyi 4 Haziran 2020 tarihinde yaptığı toplantıda para politikası ile ilgili bazı kararlar almıştır. Politika faiz oranı $\% 0$, günlük vadeler için uygulanan marjinal borç verme kolaylığ \%0,50 olarak belirlenmiştir. Ayrıca Pandemik Acil Satın Alma Programını 600 milyar Euro arttırma kararı almıştır. Mart ayında pandemi ile mücadele için 750 milyar Euro varlık alımı ile birlikte 1,35 trilyonluk bir paket uygulanmaya konulmuştur. Konsey, koronavirüs salgınının bittiğine dair sinyaller alınana dek net varlık alımlarının sürdürüleceğini ifade etmiştir (ECB, 2020). Benzer bir hamle ile Amerikan Merkez Bankası (FED) Federal Açık Piyasa Komitesi (FOMC) Mart ayında yaptığı iki toplantıda hedeflenen fonlama faiz oranını \%0'a yakın bir seviyede tutma kararı almıştır. Fiyat istikrarının sağlanması hedefi ile birlikte talepteki ve petrol fiyatlarındaki düşüşün de etkisi ile ekonomik faaliyetleri harekete geçirmek maksadıyla daha önce belirlenen \%0-0,25 aralığının sürdürülmesine karar vermişlerdir. Bu anlayışla birlikte hem hazine tahvillerinin hem de mortgage bağlı menkul kıymetler tahvillerinin alımının sürdürüleceği vurgusu yapılmıştır (Monetary Policy Report, 2020:3).

Ekonomik krizlerin baş göstermesiyle uluslararası sermaye çıkışı gelişmekte olan ülkeler için en ciddi handikaplardan biridir. İktisadi aktörler yüksek getiri elde etmek için genellikle gelişmekte olan ülkelerden finansal varlık edinirler. Kriz belirtileri finansal panik halini alınca söz konusu ülkenin yerli para cinsi terk edilerek dolar, euro gibi rezerv para gücüne sahip bir dövize rağbet edilir. Bu durum dövize olan talebi artırır. Yerli para biriminin değeri düşer. 2008-09 Küresel Krizi sonrası edinilen edinimlerden biri de gelişmekte olan ülkelerde sermaye çıkışının küreselleşme ile birlikte gelişmiş ülkeleri etkileme durumunun fark edilmesidir. Bu bağlamda hem Amerika Merkez Bankası (FED) hem de Avrupa Merkez 
Bankası (ECB) yaptıkları hamlelerle sermaye gereksiniminin derinleşmesini engellediler. Sunulan acil durum paketleri ve de swap kanalı ile nispi olarak da bu durumun negatifliği azaltılmıştır. Bu doğrultudaki uygulamalar aynı zamanda oluşabilmesi muhtemel bir finansal kriz bulaşıcılığını da engellemiştir.

\section{Gelişmekte Olan Ülkeler ve Covid-19 Pandemisi}

Gelişmekte olan ülkelerde yaşanan küresel şoktan etkilenme derecesinin yüksek olma olasılığının nedenleri iki ana başlıkta ele alınabilir. Bunlar küresel şoklar ve yapısal kaynaklı sebeplerdir. Gelişmekte olan ülkelerin büyüme kaynaklarını belirlemede etkili olan hammadde başta olmak üzere ihracatın (dış talep şoku nedeni ile), döviz girdisi sağlayan işçi dövizlerinin, önemli bir döviz kaynağı olan turizm ve buna bağlı olarak hizmetlerin azalması, ticari malların fiyatlarının düşmesi ve de finansal piyasalara ulaşmanın zor ve maliyetli olmasıdır. Küresel talep azalması nedeniyle Brent ham petrol fiyatları bu süreçte \%63 düşmüştür. Analize başka emtialar eklendiğinde (endüstriyel metaller, değerli madenler [altın hariç], tarım ve hayvancılık) genel fiyatlardaki düşüş \% 37 olmuştur (UNCTAD, 2020: 4:5).Yapısal kaynaklı sorunlar ise halk sağlığı kapasitesinin yetersizliği, fon ve kaynakların dağıtımının sağlanması için düşük bir mali alanın varlığı, şokları yönetmek için mevcut yönetişimin zayıf olması, emeğin kayıt dışılığı (işsizlik sigortası, ücretli izin, istikrarlı bir gelirin olmaması, yetersiz tasarruf) gibi unsurlardır (Layza ve Pennings, 2020).

Halk sağlığını korumak için alınan önlemler ve yürürlüğe konulan kısıtlamalar birçok tüketici ve üreticinin ekonomik faaliyetlerinde ani bir düşüşe neden olacaktır. Bu kriz unsurları zincirleme etkiler yaratarak hem gelişmiş hem de gelişmekte olan ülkeler için şu ana dek görülmemiş bir şokun habercisi konumundadırlar. Aralarındaki nüanslarla beraber zayıf bir sağlık sistemine sahip olan gelişmekte olan ülkelerin gelir ve büyüme kaynaklarının küresel ticarete, turizme ve emtia ihracatına bağlı olduğu düşünüldüğünde gelişmekte olan ülkelerin zor bir süreç ile karşı kaşıya kalacakları tahmin edilmektedir. Pandeminin yarattığı derin durgunluk düşük yatırım kararları, işsiz kalanların beşerî sermayelerinin aşındırması ve tedarik sürecindeki sıkıntılar gibi birçok kanal aracılığıyla söz konusu etkilerin kısa vadenin ötesinde uzun vadede hem büyüme hem de işgücü verimliliğine sekte vurarak üretkenliği düşüreceği yönünde bir gözlem mevcuttur (World Bank, 2020:133).

Dünya Bankası Raporu'na göre gelişmekte olan ülkeler pandemi sürecini gelişmiş ülkelere nazaran daha az bir negatif büyüme ile tamamlayacaklardır. Birleşik Devletler (ABD), Avrupa Bölgesi ve Japonya'yı içine gelişmiş ülkeler için 2020 Reel GSYİH -\%7 iken yükselen piyasalar ve gelişmekte olan ülkeler için bu oran Çin'in ağırlığı göz önünde bulundurulmak kaydıyla -\%2,5 olarak tahmin edilmektedir. 2021 için sırasıyla büyüme tahminleri $\% 4,2$ ve \%4,6'dır (World Bank, 2020:4). Nispi olumlu bir tablo ile birlikte gelişmekte olan ve yükselen ekonomilerin ülke nüfusları dikkate alındığında kişi başına düşen GSYH'nin düşük bir seviyeye gerileceği görülecektir.

Gelişmekte olan ekonomiler gelişmiş ülke ekonomileri ile kıyaslandığında sahip olunan basit ve sı̆̆ bir finansal yapı ve borçlanmaların döviz cinsinden varlıklara dayanması gibi hususlar sermaye akışına duyulan ihtiyacı gösterirken sermaye hareketlerinin ülkelerin makro iktisadi değişkenlerde istikrarsızlıklara doğrudan ve dolaylı etkileri etki edildiği unutulmamalıdır (Bilanchard vd., 2019:11). Bu sürecin küresel ölçekte ekonomik etkileri ve olumsuz yansımaları kuşkusuz farklı olacaktır. 2008-09 küresel finans krizi sonrası düşük büyüme oranına ve kırılgan bir yapıya sahip olan küresel ekonomi için Covid-19 salgını bu sürecin yıkıcı yansımalarını derinleştirecektir. Gelişmekte olan ülkeler gelişmiş ülkeler ile kıyaslandığında yapısal reformların gerekliliği, sahip oldukları paraların rezerv para olmaması belki de en önemlisi ekonominin iki kötüsü olarak kabul edilen enflasyon ve yüksek işsizlik (Abel vd., 2014:449) ile boğuşmalarıdır. Bu bağlamda herhangi bir altın, doğalgaz, petrol gibi 
bir doğal kaynağa sahip olmamak ve sürekli yatırımların finansmanı için uluslararası sermaye ihtiyaç duyulması kırılganlığı artıran hususlardır.

Büyüme, işsizlik, enflasyon, diş ticaret ve ülke bütçelerine dair veriler genellikle aylık bazda ele alınıp değerlendirildiğinden CDS primleri kısa vadede (günlük bazda) ülkelerin risk durumunu, primini ve borçlarını ödeyebilme durumunu göstermesi açısından önemli bir parametredir. Bu bağlamda dış borçların GSYİH'a oranının yüksek olması risk pirimini artıran unsurlardan biri olarak kabul edilmektedir. Ülkelerin borçlarını ödeyememe riskinin artması finansal kırılganlığı artırır. Söz konusu riskin bir göstergesi de CDS primleridir. CDS (Credit Default Swap), kredi temerrüdüne dayalı takas sözleşmesi olarak Türkçeye çevrilebilir. Bir finansal varlığın ödeyememe riski nedeni ile kredi riskini bir başka kurumun yüklenmesidir. $\mathrm{Bu}$ sözleşmelerde iki taraftan biri olan finansal varlık sahibinin kredi sonrası sahip olduğu varlığın nominal değerini karşılamak için bir başka kurum tarafından kredinin korunmasıdır (O'Kane ve Turnbull, 2003:1). Risk derecesi yüksek olan bir ülkeden tahvil alındığını varsayalım. Riskten korunma maksadı ile CDS satın alan bir kuruma tahvilinizi veriyorsunuz. Şayet devlet çıkardığı tahvilin karşılığı yükümlülüklerini yerine getirmezse CDS'yi satan kurum satın alınan tahvilin değerini öder. Tam manasıyla karşılık gelmese de bu durum kredinin sigortalanmasıdır. Bu bağlamda bir ülkenin risk durumunun artması CDS'yi satan kurumun yüksek prim istemesi ile sonuçlanır (Özatay, 2015:16-17). CDS priminin yüksek olması o ülkenin veya şirketin borçlanma maliyetinin yüksek olduğunu gösterir. Bu doğrultuda söz konusu riskleri ölçmek için objektif bir kıstas 5 yıllık CDS primleridir. Ülke ekonominde CDS priminin 300 bp (baz puan) üzerinde olması o ülke için kırılganlık seviyesinin arttığını açıklar ve aşırı kırılganlığın belirtisi olarak ifade edilir. CDS primlerinin yükselmesinin nedenlerinden biri diş nedenlerdir (diğeri iç nedenler). Dış nedenlerden en bariz olanı Covid-19 salgını nedeni ile virüsün yayılma hızının artması ekonomik faaliyetlere sekte vurmuş olmasıdır (Eğilmez, Mart 2020).

Tablo 1: Seçilmiş Gelişmekte Olan Ülkelerin 5 Yıllık CDS Primleri (2020)

\begin{tabular}{lccc}
\hline \hline Ülkeler/Tarih & 1 Ocak & 25 Mart & 17 Haziran \\
\hline \hline Brezilya & 99,010 & 298,410 & 256,300 \\
Endonezya & 65,560 & 220,000 & 120,754 \\
Güney Afrika & 159,09 & 347,710 & 278,370 \\
Hindistan & 65,910 & 237,620 & 115,040 \\
Misir & 275,00 & 650,000 & 504,490 \\
Pakistan & 350,00 & 691,530 & 583,860 \\
Türkiye & 278,37 & 516,12 & 464,150 \\
\hline \hline
\end{tabular}

Kaynak: www.worldgovernmentbonds.com

www.investing.com

Yukarıda Tablo 1'de kırılgan ülke ekonomileri dahil gelişmekte olan seçilmiş bazı ülkelerin 5 Yıllık CDS primleri yer almaktadır. Çin'den yayılan virüsün kıtalararası bir hal almadığı Ocak ayı, zirve yaptığı Mart ayı ve normalleşme ayı olarak ifade edilen Haziran olmak üzere üçer aylık aralıklarla belirli günlerin CDS primleri gösterilmiştir. Ocak döneminde sadece 
kritik eşik olan 300 bp'nin üzerinde olan Pakistan iken mart ayının sonlarına doğru bütün ülkelerin CDS primleri artmış ve bu sayı dört ülkeye (Güney Afrika, Mısır, Pakistan ve Türkiye) çıkmıştır. FED ve ECB başta olmak üzere Merkez Bankalarının çoğunluğunun politika faiz oranı düşürmesi, OECD ve Dünya Bankası'nın parasal genişlemeyi desteklemesi ile birlikte ekonomik aktivitelerin olağan seyrinden çok uzakta olsa kimi iyileşme belirtileri göstermesi haziran ayında CDS primlerinin düşüşünü gösterse de (Şekil 1'de Ocak, Mart ve Haziran 2020'nin aylık ortalama 5 yıllık CDS primleri gösterilmektedir. Ters V şeklinde olması iyiye gidişin bir işareti olarak yorumlanabilir) bu sürecin kısa vade ile sınırlı kalmayıp uzun döneme yayılması ancak belirsizlik ortamının kalkması ile mümkün olacaktır. İkinci dalganın gelmesi senaryosu gelişmekte olan ülkelerin finansal kırılganlığını artıracaktır.

\section{Şekil 1: Seçilmiş Gelişmekte Olan Ülkelerin 5 Yıllık CDS Primleri (2020)}

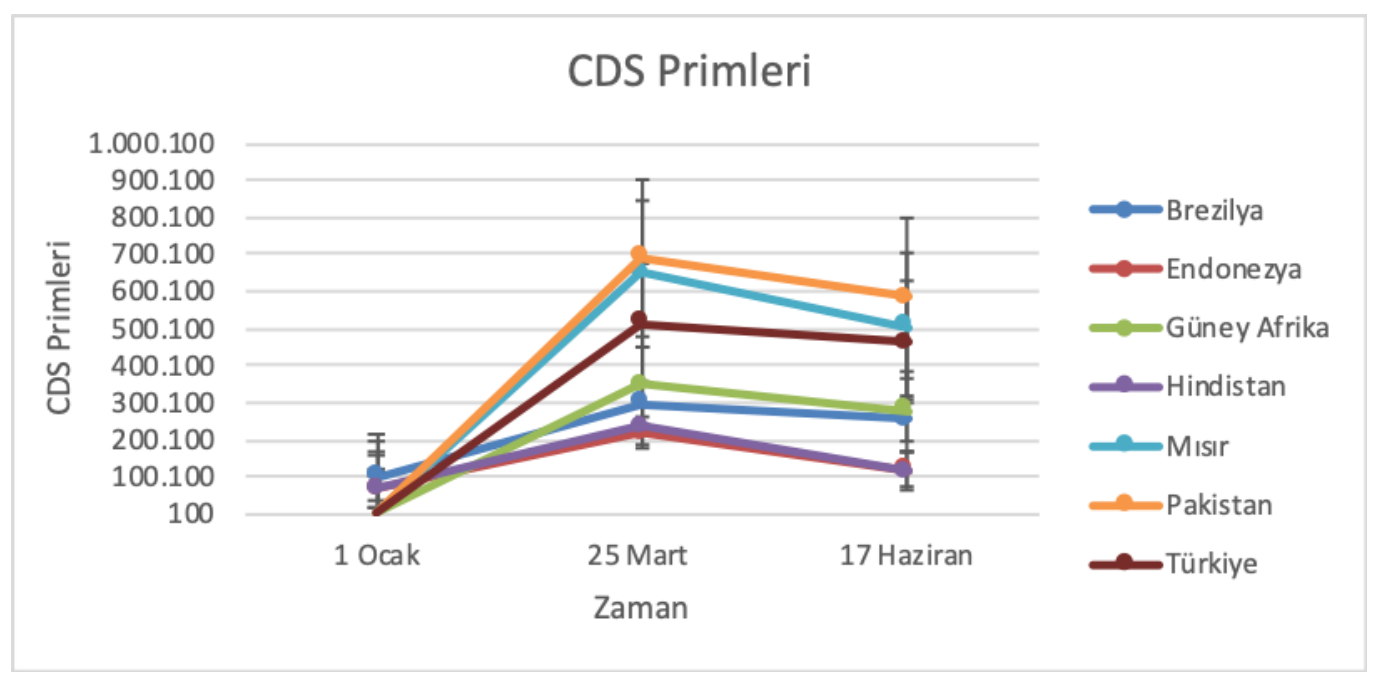

Uluslararası Finans Enstitüsü (IIF) hazırladığı rapora göre küresel borç 2019 yılında yeni bir rekor kırarak 255 trilyon dolar olmuştur. Bu seviye dünya GSYİH'sinin \% 322'sini aşmaktadır. Hükümet borçlarının yanı sıra küresel ekonomik aktivitelerdeki \% 3'lik bir daralmanın devamı neticesinde borç yükünün GSYİH'nın \%342'sini aşacağı tahmin edilmektedir. Finans kuruluşuna göre 2018 'de 3.3 trilyon dolarlık 1lımlı bir yükseliş sonrası borç birikimi 10,8 trilyon doları aşmıştır. Finans sektörü dışındaki borçlar 2018'de 183 trilyon dolar iken 2019'de 192 trilyon doların üzerine çıkmıştır. Bu artışın 4,3 trilyon dolarlık kısmı genel hükümet borç artışı ile şekillenmiştir. Gelişmekte olan piyasaların küresel borç miktarına ilavesi 3,4 trilyon doları aşmış ve toplam borç 71 trilyon doları aşmıştır. Gelişsmekte olan ülkelerde 2007 yılında borç/GSYİH \% 147 iken bu oran \% 220 sine ulaşarak en yüksek seviye olarak kaydedilmiştir. Covid-19 pandemisini atlatmak için yapılan mali teşvikler ile birlikte küresel borç yükünün 2020'de önemli ölçüde yükseleceği öngörülmektedir. Brüt hükümet borcu 2017-2019 yılları arası ortalama aylık 0.9 trilyon dolarlık borç geçen ay 2.1 trilyon doların üzerine çıkmıştır (IIF, 2020:1).

Küresel borç seviyesinin çok yüksek düzeylere ulaşmasının yanı sıra göze çarpan başka bir husus reel ekonomi ile sanal ekonomi arasındaki makasın genişlemesidir. Nitekim küresel mal ve hizmetlerin piyasa değerinin 90 trilyon dolara yaklaştı̆̆ göz önünde bulundurulduğunda söz konusu borç miktarının karşılığında üretilen mal ve hizmet bulunmaması kaygı vericidir.

Korona Sonrası: Yeni Düzen mi Geçmiş Politikalar mı? 
Covid-19 salgını sürecine girilmeseydi dünya ekonomisinin mevcut durumu ile yeni bir krizin girdabına girmemesi için neler yapılmalıydı sorusu otoritelerin sıklıkla yanıt aradığı bir alandır. Yaşanan krizi hafifletmek için yapılan borçlanma, meydana gelen bütçe açığı, mali genişleme politikalarının gerekli kıldığı bu süreç sonrası rota tekrar mali politikalara dönük olacaktır. Bu hususta iki senaryo ile karşı karşıya bulunmaktayız. Birincisi salgın olmasaydı ne tür hamleler gerekliydi ikincisi salgın sonrası nasıl bir müdahele yapılmalıdır.

Yaşanan 2008-2009 krizi sonrası ekonomi otoritelerinin yaptıkları tespitler salgın sonrası süreçte de yol gösterecektir. Nobel Ödüllü Stiglitz, 2008 krizi sonrası en önemli ve en çarpıcı dersin piyasa ekonomilerinin kendi başlarına kararlı, etkin ve kendisini düzelten bir yapıda olmadığını; krizi önleme, öngörebilme ve ortadan kaldırmak için sunulan çözüm önerilerinin ana akım modellerin varsayımı ile şekillenmesini eleştirir (Stiglitz, 2020:304). David Romer, 2008-09 Küresel Finans Krizi sonrası dünyanın hali hazırda yeni bir makro iktisadi ya da finans felaketini önleyecek bir durumda olmadığı dile getirir ve "İlk yaklaşım finans sistemini yeniden düzenleyerek finans sisteminin reel ekonomiye gönderdiği şoklart küçültmektir" şeklinde dile getirir (Romer, 2019:298-301). Avrupa Birliği Ekonomi ve Maliye Bakanları Konseyi (ECOFIN) ve İsveç Maliye Bakanlığı yapmış olan Anders Borg 2008'de yaşanan küresel ekonomik krizi sonrası alınması gereken dersleri sıralarken maliye politikasının ekonomik istikrarı sağlaması için aktif bir biçimde rol alması ve bu amacı gerçekleştirmek için kurumların bu doğrultuda reorganizasyonun sağlanmasının gerekliliğini vurgular. Başka bir ders olarak da bir ekonomide yüksek borcun varlığının rasyonel iktisat politikası açısından baskı unsuru yarattığını dile getirir. Bu bağlamda Borg'a göre aktif bir maliye politikası uygulanmasını sağlayacak husus kısa vadede değil uzun vadede borçları düşürmek olmalıdır (Borg, 2020:169). 2008-09 krizinin göstermiş olduğu derslerden biri de makro ekonomik göstergelerin bazıları örneğin enflasyon oranı, potansiyel çıktı gibi istikrarlı olsa da örneğin konut yatırımlarının neden olduğu sektörel patlamalar, yüksek kaldıraç oranına sahip finansal kurullar, hane halklarının aşırı borçlanması, bilanço bozuklukları, vade farklı uyumsuzlukları sürdürülebilir ve bütünleşik bir yapıya sahip olmayan makro iktisadi yapılar iflasa neden olabilmektedir. Bu husus sadece para ve maliye politikalarının haricinde makro ihtiyati politikaların etkin olarak uygulanmasını gerekli kılmaktadır (Bilanchard vd., 2019:22). Finansal kriz boyunca yoğun oranda para politikası ile müdahalenin arkasında yatan unsur bu politika seçiminin etkin, katı ve hızlı sonuç vermesidir ve maliye politikasının karar alma süreçlerinin ve uygulamalarının yavaş olması sebebiyledir. Buna rağmen tüm araçların kullanılması ve parasal etkinliğin sınırlarına varması durumu maliye politikasına ilgiyi arttırmıştır. Kamu otoriteleri tarafindan konulacak mali kurallar ne tür özelliklere sahip olmalıdır sorusu önemlidir. Para kurallarına benzer bir biçimde uygulanacak olan mali kuralların salt mali sürdürülebilirliği sağlayan ekonominin zayıf olduğu bir dönemde bütçe açığını yaratacak bir şekilde kamu harcamalarına olanak sağlayan ekonomik koşulların iyi olduğu zamanlarda da yeniden yapılandırılan bir borç kapasitesi ile borç/GSYH oranını düşüren bir mali disiplin uygulanması biçiminde olmalıdır (Eberly, 2019:165-166).

2008-09 global iktisat krizi sonrası uygulanan genişletici para ve maliye politikalarının temel hedefi talep daralmasını ortadan kaldırmak ve gerçekleşecek büyüme oranını en azından potansiyel büyüme oranına yakınsamasını sağlamaktır. Pandemi süreci sıfır alt limitine gelen hatta reel açıdan negatif faiz oranı ile likiditenin sağlanması yolu ile işletmelerin batmasını engellenmesi olumlu sonuçlar ortaya çıkarmıştır. Fakat kamu harcamalarını ya da vergileri düşürmek maksadıyla genişletici bir maliye politikasının etkinliği talep genişletici bir odakla hazırlanmışsa da 2008-09 küresel krizi gibi olmayacaktır. Nitekim özellikle orta ve yüksek gelir gruplarındaki tüketicilerin tüketim harcamalarını azaltması gelir yoksunluğundan değil virüsün yayılmasını engellemek için devlet tarafından ekonomik faaliyetleri yavaşlatma yaptırımı sonucudur. İktisadi aktörlerin tüketim sahası olan hizmet sektörünün bileşenlerinden bazıları 
olan turizm, seyahat, yiyecek, spor salonları virüsün yayılmasını engellemek amaciyla kısıtlanmıştır. İhtiyari bir tercih değil zorunluluk bir biçimi şeklinde yeni bir durum ile karşı karşıya bulunmaktayız. Bu bağlamda genişletici maliye politikası nasıl etkili olabilir sorusu önem arz eder.

Dünya Bankası (WB), Ekonomik Kalkınma ve İşbirliği Teşkilatı (OECD), Uluslararası Para Fonu (IMF) gibi uluslararası kurum ve kuruluşların Haziran 2020'de yayınladıkları raporda küresel ekonomik büyümeye ilişkin projeksiyon ve öngörüleri farklı olsa da belirsizliğin krizi derinleştirdiği noktasında bir konsensüs bulunmaktadır. IMF'in son raporunun başlığı süreci özetleyecek bir şekilde "Benzeri Olmayan Kriz ve Belirsiz Toparlanma/İyileşme" olmuştur. Toplam talebin büyük bir kısmını oluşturan tüketim harcamaları ile çarpan etkisiyle ekonominin büyümesine önemli katkı sağlayan yatırım harcamalarını engelleyen ve de finansal krizin nedenlerinden biri olan belirsizlik (Mishkin, 2004:189) hali politika yapıcıların müdahale alanını ciddi bir biçimde kısıtlamaktadır. Krizin minimal bir hasarla atlatılması için korumacı neo-merkantilist reaksiyonların aksine küresel işbirliğinin artması vurgulanmaktadır.

Koronavirüs (Covid-19) salgını sonrası ekonomik durgunluğun nasıl bir seyir izleyeceği ve bu seyrin şeklinin ne olacağı ile ilgili alfabede yer alan harfler üzerinden senaryolar inşa edilmektedir. İktisat tarihinden yaşanan durgunluklar ve bu durgunlukların iyileşme süreçleri ile ilgili dört yaygın tanımlama bulunmaktadır. V, U, W ve L tipi biçimindeki olasılıklar. Söz konusu harfler GSYİH, istihdam ve ekonomik koşulların seyrini belirleyen parametrelere dayanmaktadır. V tipi iyileşme en iyi senaryo olarak ifade edilir. Keskin bir gerilemeyi ciddi bir ekonomik büyüme izler. Nitekim Merkez Bankaları ve hükümetler bu kriz sürecini atlatmak için hem mali hem de parasal teşvik uygulamalarını yürürlüğe koydular. Bu türden bir senaryo en az finansal hasarla iyileşme moduna geçmeye olanak sağlar. Sürecin olası V tipi üzerinden okunmasına olanak sağlayacak sinyaller üretim faaliyetlerinin başlamasına ve talep canlılığına neden olacak bir şekilde vakaların yayılma hızını azaltacak, mevcut vakaların iyileşmesini sağlayacak ve yeterli koronavirüs testleri ile sağlanılabilecektir. U tipi iyileşme, daralmanın başlangıcı ile iyileşme arasında uzun süre geçeceğinin ifadesidir. Böyle bir durgunluktan çıkış ve ekonominin toparlanması için belirli bir süre geçmesi gerekir. En son yaşanan küresel finansal kriz 2007'nin Aralık ayında başlayıp 2009'un Haziran ayına kadar süren 19 aylık bir süreç almış ve büyüme ve istihdamın eski seviyesine dönmesi için dört çeyrekten daha fazla bir zaman almıştı. Koronavirüs vakalarının kontrol altına alınması uzun sure alacak gibi görünmekte ve bu nedenle ekonomik toparlanmanın 2020'nin sonu hatta 2021 'n başıın bulacağ anlamına gelmektedir. İşletmelerin iflası ve tüketicilerin mal ve hizmetleri talep etmemeleri bu sürece neden olacaktır. W tipi iyileşmede sosyal izolasyonun ve alınan önlemlerin gevşetilmesi sonrası iktisadi faaliyetlerin artması hızlı toparlanma meydana gelir fakat sürecin ikinci dalgaya neden olması tekrar bir biçimde ekonomik faaliyetlerde düşüşe neden olur. W tipi iyileşmede iki ekonomik daralma yaşanır. İkinci salgın dalgasının yaşanması W tipi krizi ihtimalini güçlendirmektedir. En kötü senaryo olarak da ifade edile L tipi iyileşmede büyüme düşer ve düşüş sonrası büyümenin görüntüsü yatay bir seyir izler. Durgunluk birkaç çeyrek sona erse bile ekonomik çıktıların durgunluk öncesine gelmesi uzun bir süreç gerektirir. Otoriteler böyle bir senaryo ihtimalinin uzak olduğu görüşünde olsalar da ekonomisi ticari mal ihracatına dayalı olan ve bu süreci büyük mali ve parasal teşvik paketleri ile desteklemeyen gelişmekte olan ülkelerin yaşayabileceği algısı vardır (Rodeck, 2020; Sarı, 2020).

Pandemi sonrası gelişmekte olan ülkelerin yeni bir krizin girdabına girmemeleri için atılması gereken adımların başında borçluluk oranının düşürülmesi gelmektedir. Şüphesiz bu kriz şimdiye dek görülmemiş bir türden bir kriz. Fakat ortaya çıkan tablo 2008-09 krizi sonrasından Pandemi sürecine kadar gelişmekte olan ülkelerin borçluluk oranının fazla olduğu gerçeğidir. Reinhart ve Rogoff (2009), “Bu Defa Farklı” isimli eserlerinde ekonominin 800 
yıllık tarihini inceledikten sonra ortaya çıkan iktisadi krizlerin nedeni olarak ülkelerin, bankaların, şirketlerin, tüketicilerin aşırı borçlanmaları olarak görmektedir. Bu bağlamda aşırı borçlanmanın yaratacağı kırılganlığı atlatmak için bu türden adımlar gereklidir. 1929 Büyük Buhran her arzın kendi talebini yaratmayacağını öğretmişti. Virüs salgını sonrası iktisat politikası araçlarının genişletici bir anlayışla uygulamaya geçilmesinin teşebbüsü bu eksende değerlendirildiğinde önemlidir. Fakat hükümetlerin aldığı bu önlemler dizisi ülkelerin borç yüklerini hem hacimsel hem de oransal olarak yükseltecektir (Çolak, 2020:19). Bu bağlamda kriz sonrası kamu borcunu kontrol etmek için krizin etkisinin azalması ile birlikte mali kurallara dönülebilir.

21.yy’da yaşanan Küresel finansal krizi ile rehber ve çözüm olarak görülen Keynesçi politikalar sonrasında ortaya çıkacak olan mali istikrarsızlık başka bir ifade ile kamu borç stokunun gelecek nesillere yükleneceği unutulmamalıdır. Ricardo-Barro hipotezinin ötesinde bu problematik durum ne pür liberal anlayış ne de aşırı regüle bir devlet modeli ile çözülecektir. Bütün bunların ötesinde sendelenen ekonomileri kamu harcamalarını artıracak bir şekilde tüketime yöneltmeye tahvil etmek en nihayetinde mali kuralları gerekli kılacaktır.

\section{Sonuç ve Öneriler}

Dünya ekonomisi yirminci yüzyıldan bugüne kadar küresel çapta etki yaratan üç büyük ekonomik krize sahne olmuştur. 1929 Büyük Buhran sonrası yine ABD kaynaklı 2008 finans krizi ekonomik dengeleri değiştirmiştir. Son krizden sonra düşük büyüme oranları ile şekillenen bir ekonomik tablo ile karşı karşıya bulunmaktayız. Finans krizi öncesi yakalanan potansiyel büyümeye tekrar yakınsama sağlamak için alınması gereken para, maliye ve makro ihtiyati politikalar tartışılırken 2019'un Aralık ayında Çin'de ortaya çıkıp dünyaya yayılan Covid-19 salgını toplumsal, sosyal, ekonomik etkileri halen süren ve süregelmesi muhtemel etkiler birakmaktadır.

Dünya Sağlık Örgütü'nün pandemi ilanından sonra salgının yayılma hızını asgari bir seviyeye indirmek için işin doğası gereği alınan önlemler, yapılan kısıtlamalar iktisadi faaliyetleri durma noktasına getirmiştir. Sürece dair küresel ölçekte olan gerek kamu gerekse özel kurum ve kuruluşların projeksiyonları belirsizlik durumu saklı kalma koşulu ile ekonomik daralma, artan işsizlik, tam istihdam seviyesinden uzaklaşma, dış ticaret faaliyetlerinin önemli ölçüde azalması, devletlerin borçluluk oranlarının azami seviyelere çıkması ve finansal kırılganlığın oluşması şeklinde yansımıştır. 2008-09 krizi sonrası elde edilen çıkarımlar doğrultusunda başta Amerika Birleşik Devletleri ve Avrupa Merkez Bankaları olmak üzere bütün ülkelerin uyguladığı politika faiz oranlarının en düşük düzeye indirilmesi, piyasaya likidite sağlamak üzere azami tahvil alımı şeklindeki parasal genişleme olası bir finansal krizi önlemiştir. Bu bağlamda kamu kesimi finansal koşulların iyileştirilmesi için işsizlik ödeneğini artıran, şirket iflaslarını engellemek için vergi borçlarının ertelenmesine olanak sağlayan, kredi imkânlarını genişleten, tüketicilere dönük sosyal ve nakdi transfer yapan bir mali genişleme mekanizması devreye sokmuştur.

Pandemi sürecini en az hasarla atlatmak için neo-merkantilist uygulamalara firsat sağlayan ve özendiren tarife, kota vb. korumacı politika araçları, Tobin vergisi benzeri uluslar arası sermaye kontrolü ve de sabit döviz kuru sisteminin özellikle gelişmekte olan ülkeler için tercih edilebilir uygulamalar olmamalıdır. Bu süreçte krizi firsata çevirmenin odak noktası otomasyonun ağırlıkta kullanılabileceği ya da esnek çalışma biçimlerinin devreye sokularak meydana getirilecek bir üretim artışını sağlam finansal dinamiklerle beslemekten geçer. Pandemi süreci ile talebi arttırmak adına düşük düzeye getirilmiş faiz oranlarının ya da likidite bolluğunun varlık balonlara ya de enflasyonist bir sürece düşme tehlikesi göz ard1 edilmemelidir. Devlet iç borçlanma senetlerinin ara hedef olduğu unutulmadan uzun vadede karlılığa dönüşmeyen kamu yatırımlarından şiddetle kaçınılması gerekir. 
Esas cevap verilmesi gereken pandemi sonrası genel anlamda küresel düzenin özelde ekonomik politikaların nasıl inşa edilmesi gereğidir sorusudur. Pandemi süreci küreselleşmenin sanıldığının aksine salt gelişmiş ülkelerin çıkarını sağladığı görüşü yeniden sorgulanmalıdır. Nitekim gelişmiş ülke ekonomileri bu sürecin gelişmekte olan ülkeler ile birlikte küresel işbirliği saikıyla atlanılabileceğini görmüş ve de bu süreçte gelişmekte olan ülkelere açılacak kredileri duyurmuşlardır. Gelişmekte olan ülkeler kriz sonrasında ekonomilerini yeniden dizayn etmek zorunda kalacaklardır. Önerilecek ve hayata geçirilecek politikalar ne regüle edilmeyen bir piyasa ne de iktisadi olarak merkeze alınmış bir devletçi anlayıştır. Pandemi sonrası artan borçluluk oranlarını sürdürülebilir/optimal bir seviyeye indirmek ve de oluşabilecek bir finansal kırılganlığı önlemek açısından yapılması gereken kuvvetli otomatik stabilizatöre sahip mali kurallar koymaktan geçer. Sıcak para dalgasının kırılganlığı her daim arttırdığı bir hengâmda cari açık, döviz kuru ve bunun enflasyona yansıması birlikte düşünüldügünde hem üretim komposizyonunun değiştirilmesi hem de katma değeri yüksek olan malların üretilmesinin önemi bir kez daha görülmektedir. Kurulacak iktisadi politikalar rijit olmayan (tek bir anlayışa dayanmadan) ve çoklu politikalara imkan verecek paradigmaya indirgenecek şekilde uygulanmalıdır. Bu hususların yanı sıra kurumsal anlayışa dayalı devlet erkleri ve yönetişim anlayışı sürdürülebilir iktisadi büyüme açısından önem arz etmektedir.

Her krizin firsat doğurduğu gerçeğinden hareketle Türkiye gibi gelişmekte olan ülkelerde maske üretiminin yanı sıra dezenfektan, tıbbi malzemeler ve en önemlisi solunum cihazının üretilmesi kayda değer bir göstergedir. Gelişmiş ülkelerde (İtalya, ABD vb.) bile sağlık politikalarının süreci en az hasarla atlatılamadığı gerçeğinden hareketle sağlık politikalarından yeni bir dönüşüm ve değişime ihtiyaç duyulduğu gözden kaçırılmamalıdır.

\section{Kaynakça}

Abel, Andrew B., Bernanke, Ben S. (2001), Macroeconomics, 4. bs., New York: Addison Wesley.

Acemoğlu, D. (2020, Nisan 1). Koronavirüs ve küresel ekonomiye etkileri. DTİK WEBINAR. Erişim adresi: https://www.youtube.com/watch?v=Zaz7YeW9Bhw.

Acemoğlu, D. (2020, Nisan 5). Koronavirüs sonrası küresel ekonomik sistem değişir mi? (K. Par, Röportaj Yapan) Habertürk TV. Erişim Adresi: https://www.haberturk.com/video/saglik/izle/acik-ve-net-5-nisan-2020-koronavirussonrasi-kuresel-ekonomik-sistem-degisir-mi-prof-dr-acemoglu-anlatiyor/681326.

Aktan, C.C., Şen, H. (2002). Ekonomik kriz: nedenler ve çözüm önerileri. Yeni Türkiye Dergisi, 2002 (1):1125-1230.

Akpınar, H. (2012). Bulaşıcı hastalıkların yayılımının tahmininde deterministik modellerin kullanılması. Öneri Dergisi, 10 (38):97-103.

Aydoğuş, O. (2020). Salgın ve ekonomik kriz. İktisat ve Toplum Dergisi, 10 (114):11-17, Ankara: Efil Yayınevi.

Blanchard, O., Della'ariccia, G., \& Mauro, P. (2019). Makro politikayı yeniden düşünmek II parçaları bir araya getirmek. G. Akerlof, D. R. Olivier Blanchard, \& J. Stiglitz (Ed.) içinde, Ne Öğrendik? Kriz Sonrası Makro İktisat Politikası, çev.(Ö. Limanlı, \& E. Kaya), s. 7-31. Ankara: Efil Yayınevi.

Borg, A. (2019). Borç gölgesinde maliye politikası: artık keynesçiliği hala işe yaramaktadır. G. Akerlof, D. R. Olivier Blanchard, \& J. Stiglitz (Ed.) içinde, Ne Öğrendik? Kriz Sonrası Makro İktisat Politikası, çev.(Ö. Limanlı, \& E. Kaya), s. 165-168. Ankara: Efil Yayınevi. 
Çolak, Ö. F. (2020). Salgına karşı ekonomik önlemler artmalı. İktisat ve Toplum Dergisi, 10 (114):18-23, Ankara: Efil Yayınevi.

Eberly, J. (2019). Maliye politikasının yeniden yükselen rolünün tanımlanması. G. Akerlof, D. R. Olivier Blanchard, \& J. Stiglitz (Ed.) içinde, Ne Öğrendik? Kriz Sonrası Makro İktisat Politikası, çev.(Ö. Limanlı, \& E. Kaya), s. 165-168. Ankara: Efil Yayınevi.

Eğilmez, M (2020). CDS primi niçin yükseliyor?. Erişim Tarihi: 05.06.2020 http://www.mahfiegilmez.com/2020/03/cds-primi-nicin-yukseliyor.html?m=1.

Federal Reserve Board (FED) (2020). Monetary policy report. Erişim Tarihi:18.06.2020. https://www.federalreserve.gov/monetarypolicy/files/20200612_mprfullreport.pdf.

International Monetary Fund (IMF), (2020). world economic outlook, April 2020: The Great Lockdown. $\quad$ Erişim $\quad$ Tarihi: $\quad 07.06 .2020$ https://www.imf.org/en/Publications/WEO/Issues/2020/04/14/World-EconomicOutlook April-2020-The-Great-Lockdown-49306.

International Monetary Fund (IMF), (2020). World economic outlook update. Erişim Tarihi: 24.06.2020https://www.imf.org/en/Publications/WEO/Issues/2020/06/24/WEOUpdate June2020.

International Labour Organization (ILO) (2020). COVID-19 and the world of work: Impact and $\begin{array}{llll}\text { policy } & \text { responses. } & \text { Erişim } & \text { Tarihi: }\end{array}$ https://www.ilo.org/wcmsp5/groups/public/---dgreports/--dcomm/documents/briefingnote/wcms_738753.pdf.

Instute Of International Finance (IIF) (2020). Global debt monitor covid-19 lights a fuse. Erişim Tarihi: 30.06.2020. https://www.iif.com/Portals/0/Files/content/Research/Global\%20Debt\%20Monitor_A pril2020.pdf.

$\begin{array}{lllllll}\text { Jones, } & \text { H. } & \text { J. (2007). Notes on } & \mathrm{R}_{0} \text {. Erişim Tarihi: 24.06.2020 }\end{array}$ https://web.stanford.edu/ jhj1/teachingdocs/Jones-on-R0.pdf.

Kermack, W. \& McKendrick, A. (1927). Contributions to the mathematical theory of epidemics. Proceedings of Royal Society of London. Series A, 115:700-721.

Kermack, W. \&; Kendrick, A. (1932). A Contribution to the Mathematical Theory of Epidemics Part II. The Problem of Endemicity. Proc. R. Soc. A. 55-83.

Kermack, W. \& McKendrick, A. (1933). A Contribution to the Mathematical Theory of Epidemics Part III. Further Studies of the Problem of Endemicity. Proc. R. Soc. A. 94122.

Loayza, N. ve Pennings, S. (2020). 2020. Macroeconomic policy in the time of covid-19: a primer for developing countries. Research and Policy Briefs, no. 28;. World Bank, Washington, DC. Erişim 23.06 .2020$. https://openknowledge.worldbank.org/handle/10986/33540.

Müftüoğlu, O. (2020, 13 Mayıs). Çözümün sırrı 'SIR' modelinde. Hürriyet. Erişim adresi: https://www.hurriyet.com.tr/yazarlar/osman-muftuoglu/cozumun-sirri-sir-modelinde41515980 .

Mishkin, F. (2004). The economics of money, banking and financial markets. Boston: Pearson, Addison Wesley.

O'Kane, D. ve S.Turnbull.(2003). Valuation of credit defaults swaps. Lehman Brothers Quantitative Credit Research Quarterly, 2003-Q1-Q2. 
Organisation for Economic Co-operation and Development OECD (2020). OECD economic outlook. Erişim Tarihi: 10.06.2020. https://www.oecdilibrary.org/docserver/0d1d1e2een.pdf?expires $=1593680203 \&$ id=id\&accname=guest \&checksum $=053 \mathrm{~F} 892270500 \mathrm{E} 4 \mathrm{C} 03 \mathrm{~A} 98 \mathrm{FAB} 15872070$.

Organisation for Economic Co-operation and Development OECD (2020). OECD employment outlook. Erişim Tarihi: 12.07.2020. https://www.oecdilibrary.org/docserver/1686c758en.pdf?expires=1594712077\&id=id\&accname=guest \&checksum=7ADC40D4F15997F16AB793D4605FDA6F.

Özatay, F., \& Sak, G. (2020). COVID-19'un ekonomik sonuçlarını yönetebilmek için ne yapılabilir? Türkiye Ekonomi Politikaları Araştırma Vakfı, 1-10. Erişim Tarihi: 20.05.2020.www.tepav.org.tr/upload/mce/2020/notlar/covid19_salgini_bir_degil_bir_ kac_ceyrek_surerse_ne_olur.pdf.

Reinhart, C.ve Rogoff, K. (2009). This time is different: eight centuries of financial folly, Oxford: Princeton University Press.

Rodeck, D. (2020, 6 Temmuz). Alphabet soup: understanding the shape of a covid-19 recession. Forbes. Erişim adresi: https://www.forbes.com/advisor/investing/covid-19coronavirus-recession-shape/.

Romer, D. (2019). Bir sonraki felaketi engellemek: ne durumdayız?. G. Akerlof, D. R. Olivier Blanchard, \& J. Stiglitz (Ed.) içinde, Ne Öğrendik? Kriz Sonrası Makro İktisat Politikası, çev. (Ö. Limanlı, \& E. Kaya), s. 165-168. Ankara: Efil Yayınevi.

Sarı, H. (2020, 15 Nisan). Virüs krizinin alfabesi: V, U, W ve L. Dünya. Erişim Adresi: https://www.dunya.com/dunya/virus-krizinin-alfabesi-v-u-w-ve-l-haberi-467772.

Stiglitz, J. E. (2019). İktisat teorisi ve politikası için kuzey atlantik krizi'nden çıkarılacak dersler. G. Akerlof, D. R. Olivier Blanchard, \& J. Stiglitz (Ed.) içinde, Ne Öğrendik? Kriz Sonrası Makro İktisat Politikası, çev.(Ö. Limanlı, \& E. Kaya), s. 165-168. Ankara: Efil Yayınevi.

Türkiye Bilimler Akademisi (TÜBA) (2020). Covid-19 küresel salgındeğerlendirme raporu. Erișim Tarihi: 24.06.2020. http://www.tuba.gov.tr/files/yayinlar/raporlar/T\%C3\%9CBA\%20Covid19\%20Raporu $\% 204 . \% 20 \mathrm{G} \% \mathrm{C} 3 \% \mathrm{BC}$ celleme\%20.pdf.

United Nations Conference On Trade And Development (UNCTAD) (2020). The covid-19 shock to developing countries: towards a "whatever it takes" programme for the twothirds of the world's population being left behind. Erişim Tarihi: 23.06.2020. https://unctad.org/en/PublicationsLibrary/gds_tdr2019_covid2_en.pdf.

Yellen, L. J. (2019). Çok hedef, çok araç: peki, biz nerede duruyoruz?. G. Akerlof, D. R. Olivier Blanchard, \& J. Stiglitz (Ed.) içinde, Ne Öğrendik? Kriz Sonrası Makro İktisat Politikası, çev.(Ö. Limanlı, \& E. Kaya), s. 33-36. Ankara: Efil Yayınevi.

World Bank (WB) (2020). Global economic prospects. Erişim Tarihi: 09.06.2020. https://openknowledge.worldbank.org/handle/10986/33748.

World Healt Organization (WHO) (2020). Virtual press conference on COVID-19 - 11 March 2020. Erişim Tarihi: 24.06.2020. https://www.who.int/docs/defaultsource/coronaviruse/transcripts/who-audioemergencies-coronavirus-press-conference-full-and-final11mar2020.pdf?sfvrsn=cb432bb3_2. 
World Health Organization (WHO) (2020). WHO Director-General's opening remarks at the media briefing on COVID-19 - 13 July 2020. Erişim Tarihi: 13.07.2020. 